\title{
The role of A268V exon-7 polymorphism of PPARA in development of axial spondyloarthritis
}

\section{Aksiyal spondiloartrit gelişiminde PPARA'nın A268V ekson-7 polimorfizminin rolü}

https://doi.org/10.1515/tjb-2021-0086

Received April 16, 2021; accepted June 22, 2021;

published online July 26, 2021

\section{Abstract}

Objectives: Axial spondyloarthritis (axSpA) is a chronic inflammatory disease that mainly affects the axial skeleton. Peroxisome proliferator activated receptor alpha (PPARA) is an intracellular transcription factor, which play a role in inflammation and osteoblasting activity. This study is designed to investigate the relationship of NG_012204.2:p.Ala268Val polymorphism of PPARA with axSpA risk and its role in disease development.

Methods: This study was conducted with 168 patients and 181 controls. Genotyping was done with MALDITOF. Gene expression level was analyzed by quantitative real time PCR (RT-qPCR). The protein homology models of PPARA were created with ProMod3. Ligand binding dynamics were tested using the AutoDock4 docking program. Statistical evaluations were made with SPSS (ver24) and GeneGlobe. Results: Our results showed that $\mathrm{C}>\mathrm{T}$ polymorphism causing NG_012204.2:p.Ala268Val change was associated with

\footnotetext{
*Corresponding author: Ekrem Akbulut, PhD, Department of Bioengineering, Faculty of Engineering and Natural Sciences, Malatya Turgut Özal University, Malatya, Turkey; and Department of Physiotherapy and Rehabilitation, Faculty of Health Sciences, Munzur University, Tunceli, Turkey, Phone: +90 53333123 16,

E-mail: ekremakbulut@gmail.com. https://orcid.org/0000-00027526-9835

Servet Yolbas, Department of Rheumatology, Faculty of Medicine, İnonu University, Malatya, Turkey. https://orcid.org/0000-00018516-9769

Metin Ozgen, Department of Rheumatology, Faculty of Medicine, Ondokuz Mayıs University, Samsun, Turkey
}

disease risk ( $\mathrm{p}=0.024)$ and $\mathrm{T}$ allele increased disease risk 1.7 times (95\% CI=1.070-2.594). PPARA expression decreased $(\mathrm{p}<0.05)$ in individuals carrying the $\mathrm{T}$ allele. We determined that the ligand entry pocket was opened $1.1 \AA$ An the polymorphic PPARA. Polymorphic change caused a decrease in the ligand binding affinity.

Conclusions: Our results provide an important contribution to elucidating the development of axSpA and demonstrate the potential of PPARA as a marker for the diagnosis of axSpA.

Keywords: axial spondyloarthritis; disease risk; inflammation; peroxisome proliferator activated receptor alpha; polymorphism.

Öz

Amaç: Aksiyal spondiloartrit (axSpA), aksiyal iskeleti etkileyen kronik enflamatuar bir hastalıktır. Peroksizom çoğaltıcılar tarafından aktive edilen reseptör (PPARA), enflamasyon ve osteoblast aktivitede rol oynayan hücre içi bir transkripsiyon faktörüdür. Bu çalışma, PPARA'nın NG_012204.2:p.Ala268Val polimorfizminin axSpA riski ile ilişkisini ve hastalık gelişimindeki rolünü araştırmak için tasarlanmıştır.

Yöntem: Bu çalışma 168 hasta ve 181 kontrol ile yürütüldü. Genotipleme MALDITOF ile yapıldı. Gen ekspresyon seviyesi nicel gerçek zamanlı PCR (RT-qPCR) ile analiz edildi. PPARA'nın protein homoloji modelleri ProMod3 ile oluşturuldu. Ligand bağlanma dinamikleri, AutoDock4 yerleştirme programı kullanılarak test edildi. İstatistiksel değerlendirmeler SPSS (ver24) ve GeneGlobe ile yapıldı.

Tartışma: Sonuçlarımız, NG_012204.2:p.Ala268Val değişikliğine neden olan $\mathrm{C}>\mathrm{T}$ polimorfizminin hastalık riski ile ilişkili olduğunu ( $\mathrm{p}=0.024)$ ve $\mathrm{T}$ allelinin hastalı riskini $1.7 \mathrm{~kat}$ 
arttırdığını (\%95CI=1.070-2.594) gösterdi. T allelini taşıyan bireylerde PPARA ekspresyonu azaldı $(\mathrm{p}<0.05)$. Polimorfik PPARA'da ligand giriş cebinin 1.1 Â açıldığını belirledik. Polimorfik değişiklik, ligand bağlanma afinitesinde bir azalmaya neden oldu.

Sonuç: Sonuçlarımız, axSpA'in gelişim mekanizmasını aydınlatmaya önemli bir katkı sağlar ve PPARA'nın axSpA tanısı için bir belirteç olarak potansiyelini göstermektedir.

Anahtar kelimeler: aksiyal spondiloartrit; hastalık riski; enflamasyon; peroksizom çoğaltıcılar tarafından aktive edilen reseptör alfa; polimorfizm.

\section{Introduction}

Axial spondyloarthritis (axSpA) is a polygenic inflammatory disease [1]. Ankylosing spondylitis (AS) is a subtype of axSpA and presents radiographic manifestations [2]. It is known that approximately 6.5 million people worldwide suffer from AS [3]. The axial skeleton is the most severely affected by the disease [4]. New bone formation is important in axSpA. An increasing inflammation aggravate the disease, inducing new bone formation and ankylosis [5]. Inflammation can, over time, cause structural damage to the axial skeleton resulting in restriction of spinal mobility [6]. Other than by imaging, there is no direct test to diagnose axSpA. There is no serologic or blood marker specific for the disease [7]. The mean delay from the onset of symptoms to the diagnosis of axSpA can be as long as 14 years, with longer delays in females [8]. In recent years, studies have reported that the presence of axSpA increases the risk of cardiovascular disease and mortality [9]. Diagnosis of the disease in the early stages, before it causes structural damage and loss of the workforce among young people, is the priority of scientific research [10]. Therefore, there is an urgent need for biological markers to provide early diagnosis of the disease.

PPARA is an intracellular transcription factor, activated by fatty acids, which play a role in inflammation [11]. PPARA, regulates in negatively control of pro-inflammatory proteins [12]. The activation of PPARA is related to the transcription of about 100 genes involved in fatty acid oxidation, lipid metabolism and inflammation [13]. PPARA plays multiple regulatory functions, including the control of macrophage activity and inflammation. PPARA ligands significantly reduce levels of pro-inflammatory cytokines (TNF, IL-6 and IL-1) $[14,15]$. Studies show that many genetic factors may be associated with the risk of development and prognosis of $\operatorname{axSpA}[16,17]$.
In this study, the association between PPARA, NG_012204.2:p.Ala268Val (rs1042311) polymorphism and disease risk was investigated in patients with axSpA.

\section{Patients and Methods}

\section{Study protocol}

In the study design, the association between NG_012204.2:p.Ala268Val change and disease risk was shown among case (n:168) and control (n:181) groups. Afterwards, expression levels of PPARA gene from blood tissue of 14 patients (TT) with risk allele and 14 healthy control (CC) were examined. The change induced by NG_012204.2:p.Ala268Val polymorphism in protein structure was modeled. The effect of polymorphic change on PPARA ligand binding affinity was investigated. The study was recruited at Turgut Özal Medical Center of İnönü University, Malatya, Turkey, from 2016 to 2018.

\section{Study groups}

This study comprised 168 axSpA patients and 181 controls recruited from the department of Rheumatology. A complete clinical evaluation was performed for all patients. Healthy individuals were selected for control group. Data collection form included information such as gender, age, disease duration. BASDAI (Bath Ankylosing Spondylitis Disease Activity Index) was used to calculate disease activity scores.

\section{SNP selection and genotyping}

We retrieved the reference SNPs (rs) identified for PPARA from the NCBI database and identified potential functional SNPs based on the following criteria: (i) located in exon regions; (ii) axSpA has not been associated with disease risk in published genome-wide association studies; (iii) potential functional SNPs identified using the SNPinfo software; (iv) causing a missense change; (v) SNPs located in and around the PPARA ligand binding site. As a result, the rs1042311 polymorphic region was examined in this study.

DNA isolation from peripheral blood samples was performed using Invisorb Spin Blood Mini Kit ${ }^{\mathrm{TM}}$ (Catalog Number: 1031100300). To ensure successful multiplex PCR, it was ensured that DNA concentrations were at least $20 \mathrm{ng} / \mu \mathrm{l}$ for each sample. Target polymorphic region (rs1042311- NG_012204.2:p.Ala268Val) were amplified by multiplex PCR using designed primer pairs and probe. The forward and reverse primers sequence were ACGTTGGATGTGTGTATGGCTGAGAAGACG and ACGTTGGATGTGGCAGCAGT GAAAGATGCG, respectively. The sequence of single base extension probe was GGGTTGCATCCAGAACAAGGAGG. The reaction was performed as 45 cycles with predenaturation at $95^{\circ} \mathrm{C}$ for $3 \mathrm{~min}$, denaturation at $95^{\circ} \mathrm{C}$ for $30 \mathrm{~s}$, binding at $56^{\circ} \mathrm{C}$ for $30 \mathrm{~s}$, elongation at $72^{\circ} \mathrm{C}$ for $1 \mathrm{~min}$ and final elongation at $72^{\circ} \mathrm{C}$ for $5 \mathrm{~min}$. The total volume of reaction was $5 \mu \mathrm{L}$ with the $2.5 \mathrm{mM}$ of $\mathrm{MgCl}_{2}$, $2 \mathrm{ng}$ of sample DNA, 1 enzyme unit, $0.1 \mu \mathrm{M}$ of primer and $500 \mu \mathrm{M}$ of dNTP as the final concentration in PCR. Next, $0.5 \mathrm{ml}$ of Shrimp alkaline phosphatase was added to the samples for dNTP neutralisation after multiplex PCR, and the samples were then incubated 
at $37^{\circ} \mathrm{C}$ for $40 \mathrm{~min}$. The samples were further incubated at $85^{\circ} \mathrm{C}$ for $5 \mathrm{~min}$ for enzyme inactivation. Next, $0.041 \mu \mathrm{L} 1 \mathrm{X}$ enzyme, $0.940 \mu \mathrm{L}$ elongation primer and $0.2 \mu \mathrm{L}$ termination mixture were added to the samples for the identification of the polymorphic base, and PCR was performed as 42 cycles with pre-denaturation at $95^{\circ} \mathrm{C}$ for $30 \mathrm{~s}$, denaturation at $95^{\circ} \mathrm{C}$ for $5 \mathrm{~s}$, binding at $52^{\circ} \mathrm{C}$ for $5 \mathrm{~s}$, elongation at $80^{\circ} \mathrm{C}$ for $5 \mathrm{~s}$ and final elongation at $75^{\circ} \mathrm{C}$ for $2 \mathrm{~min}$. The genotyping analysis was performed by MALDI TOF.

\section{Quantitative gene expression analyzes}

The gene expression changes of wild type and polymorphic of PPARA were analyzed by qPCR. Total RNA was isolated from peripheral blood using an RNA extraction kit according to the manufacturer's instructions (RNeasy Plus Mini Kit, QIAGEN). RNA was reverse transcribed using a cDNA conversion kit (QIAGEN, RT ${ }^{2}$ HT First Strand Kit, Cat No: 330411). The cDNA in combination with $\mathrm{RT}^{2} \mathrm{SYBR}^{\circledR}$ Green qPCR Mastermix (Cat. No. 330529) was used with RT2 qPCR assays. qPCR procedure was performed in a total reaction volume of $25 \mu \mathrm{L}$. The $C_{\mathrm{T}}$ cut-off was set to 35 . The forward and reverse primers sequence for PPARA were CTATCATTTGCTGTGGAGATCG and AAGATATCGTCCGGGTGGTT, respectively. The forward and reverse primers sequence for GAPDH were TGGGTGTGAACCATGAGAAG and GCTAAGCAGTTGGTGGTGC, respectively.

For each sample, data of the PPARA were normalized with the GAPDH. In the study, the $C_{\mathrm{T}}$ values belonging to 3 repetitions of the samples were averaged. $C_{\mathrm{T}}$ averages of the GAPDH gene were subtracted from the $C_{\mathrm{T}}$ averages of the target gene and the data were normalized. The $2^{\Delta \Delta C}$ f formula was applied to the data of the normalized samples and the obtained raw data were made suitable for the statistical study to be used. In order to determine the difference between gene expression levels between case and control groups, $\Delta \Delta C_{\mathrm{T}}$ and $2^{\Delta \Delta C}{ }_{\mathrm{T}}$ analysis were done with Gene Globe application.

\section{Modeling of polymorphic PPARA}

The homology model of polymorphic PPARA was built based on the target-template alignment using ProMod3 (ver3.1.1) [18]. 1K7L (protein data bank) was selected as template. Protein sequence data was edited with MegaX [19]. ProSA and Molprobity were used for structural validation and model of wild type and polymorphic PPARA [20, 21]. Topological differences of wild type and polymorphic PPARA were calculated with the i-Tasser TM-Score [22]. The modeling results were visualized with PyMOL ${ }^{\mathrm{TM}}$ (ver2.4.1).

\section{Protein stability analyzes}

The changes in protein stability was performed using mCSM stability [23], DUET [24], DynaMut2 [25] and SDM [26].

\section{Docking}

The modeled structures of both wild type and polymorphic PPARA were used as targets and 2-(1-methyl-3-oxo-3-phenyl-propylamino)-3\{4-[2-(5-methyl-2-phenyl-oxazol-4-yl)-ethoxy]-phenyl\}-propionic acid (CID 446642) was used as ligands for molecular docking using AutoDock 4.2 [27]. Kollman charges were added to the PPARA wild type and polymorphic homology models. Gasteiger partial charges were applied to the ligands. Docking were performed with a grid dimension of $74 \times 92 \times 88(-17.189,-11.029,-5.596)$ with a grid spacing of $0.336 \AA$ around the binding pocket. Docking simulations were performed Lamarckian genetic algorithm (LGA) [28]. The main selected LGA parameters were 100 runs, $2.7 \times 10^{4}$ generations and population size of 300. A maximum of $2.5 \times 10^{7}$ energy evaluations was applied for each experiment. The results were clustered according to binding energy scores using a tolerance of $2.0 \AA$ RMSD. Docking results were visualized with Discovery SV (ver20.1, DDS Biovia).

\section{Statistical analysis}

The correlation of NG_012204.2:p.Ala268Val replacement with disease risk was analyzed by logistic regression test (SPSS 24.0, Chicago). Power analysis was perform by using PS Power and Sample Size Program 3.1.2. Hardy-Weinberg equilibrium was evaluated by $\chi 2$ analysis. Demographic data were given as mean \pm standart deviation and $\min /$ max values. "p" value smaller than 0.05 was regarded as statistically significant. The statistical evaluation of the difference between PPARA expression levels between the case and control groups was done with $t$-test by GeneGlobe.

\section{Results}

The study group clinical and demographic data showed that the incidence of the disease in men was found to be 2.8 times higher than in women $(\mathrm{p}<0.05)$. The mean age of the patient group was $37.93 \pm 11.09$ and the mean age of the control group was $39.75 \pm 10.42$. Data obtained by genotyping in rs1042311 (NG_012204.2:p.Ala268Val) polymorphic region are given in Table 1 . It was found that $\mathrm{C}>\mathrm{T}$ polymorphism causing NG_012204.2:p.Ala268Val change was associated with disease risk $(\mathrm{p}=0.024)$ and $\mathrm{T}$ allele increased disease risk 1.7 times ( $95 \% \mathrm{CI}=1.070-2.594)$. The BASDAI score of the patients was $6.78 \pm 1.32$.

The data of the qPCR study results with patient individuals carrying the $\mathrm{T}$ allele are given in Table 2 . It was determined that PPARA expression decreased $(\mathrm{p}<0.05)$ in individuals carrying the $\mathrm{T}$ allele (Figure 1).

The change caused by NG_012204.2:p.Ala268Val in the PPARA tertiary structure was modeled with Promod3. The quality analysis of the polymorphic PPARA model was

Table 1: Genotyping results.

\begin{tabular}{lrlrrrr}
\hline A268V & $\begin{array}{r}\text { Control } \\
\mathrm{n}: 181\end{array}$ & $\begin{array}{r}\text { Case } \\
\mathbf{n}: 168\end{array}$ & $\begin{array}{r}\mathbf{p} \\
(\mathbf{p}<0.05)\end{array}$ & $\begin{array}{r}\text { OR } \\
(\% 95 \mathrm{Cl})\end{array}$ \\
\hline $\mathrm{CC}$ & 87 & & 63 & 0.36 & 0.024 & $1.67(1.070-$ \\
$\mathrm{CT}$ & 83 & 0.29 & 89 & & & $2.594)$ \\
$\mathrm{TT}$ & 11 & & 16 & & \\
\hline
\end{tabular}

*MAF, Minor allele frequency. 


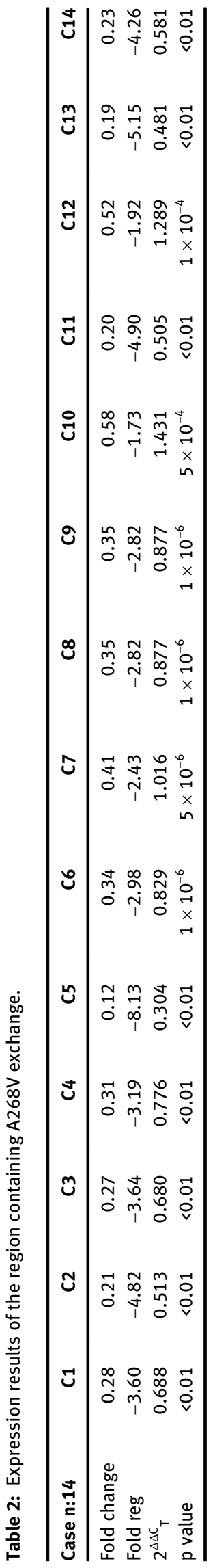

done with ProSA and molprobity. The quality scores of the variant model were found within NMR quality limits $(Z$ score -8.64) (Figure 2). Structural and conformational differences between the polymorphic model and the model of wild type were analyzed with the i-Tasser's TM-score tool. TM-score was 0.99. RMSD value was 1.397 . The results indicate high similarity between wild type and polymorphic PPARA. Protein stability analyzes revealed that the polymorphic change destabilising the protein. DynaMut2, mCSM, DUET and SDM $\Delta \Delta \mathrm{G}$ scores were $-0.690,-0.478,-0.450$

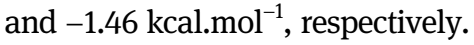

In this study, it was determined that NG_012204.2: p.Ala268Val change cause a decrease in ligand binding affinity. The ligand (2-(1-methyl-3-oxo-3-phenyl-propylamino)-3-\{4-[2-(5-methyl-2-phenyl-oxazol-4-yl)-ethoxy]phenyl\}-propionic acid) was docked to the ligand binding site of wild type PPARA, the binding energy was between -11.58 and $-6.82 \mathrm{kcal} \mathrm{mol}^{-1}$ and was found 94 number of distinct conformational binding clusters. The binding energy of polymorphic type was between -10.92 and $-6.26 \mathrm{kcal} \mathrm{mol}^{-1}$ and was found 100 number of distinct conformational binding clusters (The top 10 conformation with the lowest binding energy for wild type and polymorphic PPARA are given in Table 3). The considering the lowest binding energies, the wild type with ligand interacted at 22 points (Figure 3), while the polymorphic type interacted at 19 points (Figure 4). The hydrogen bond interaction was observed to be 5 (Thr279:OG1, Ala333:N, Phe273:CA, Ser280:OG, Cys276:SG with ligand) in wild type PPARA and 3 (Lys358:HZ1, Lys358:HZ2, His440:CE1 with ligand) in polymorphic.

We determined that the polymorphic change causes an alteration in the protein three-dimensional structure in the ligand entry pocket (Figure 5). We determined that the distance between the residues 268:CA and 244:CA in the ligand entry pocket is $7.7 \AA$ in the wild type PPARA, while this distance is $8.8 \AA$ in the polymorphic PPARA. Also, the distance between positions 268:CB and 244:SD was $3.7 \AA$ in wild type and $6.3 \AA$ in polymorphic PPARA.

\section{Discussion}

axSpA is the typical form of a family of diseases known as spondyloarthritis characterized by inflammatory processes and new bone formation [29]. Irreversible joint and organ involvement, which significantly affects the quality of life of the patients due to the late diagnosis, is one of the most important problems [30]. The first study revealed that NG_012204.2:p.Ala268Val polymorphism of PPARA is associated with the risk of axSpA disease. It has been 


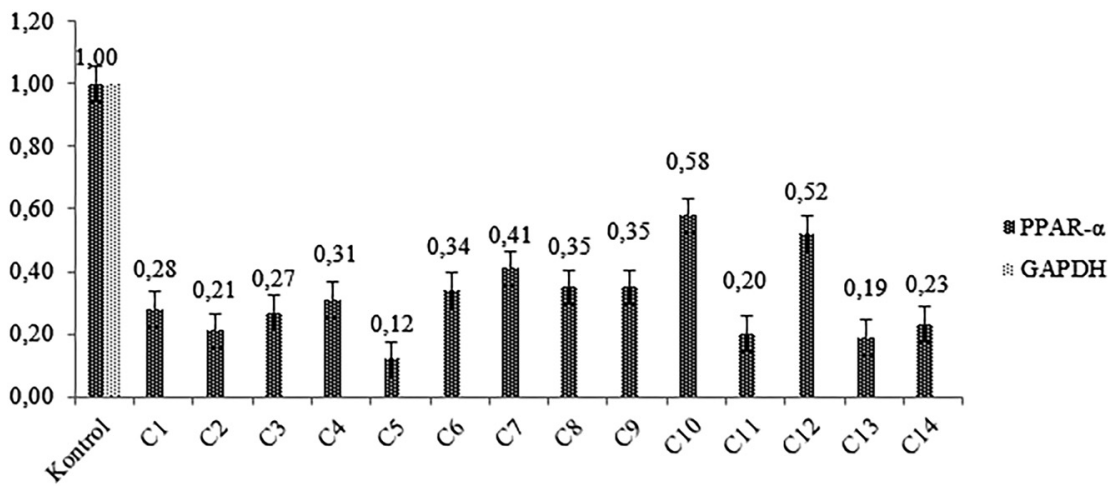

Figure 1: PPARA expression fold change.

shown that the change of alanine to valine at the 268th position in the protein structure causes a change in the ligand entry pocket, that may affect functional properties and gene expression. It was confirmed by qPCR analysis that polymorphic change caused a decrease in PPARA expression levels. The data to be obtained from the study will contribute to the identification of genetic markers that will contribute to the diagnosis of the disease in the early period, before spinal deformation progresses, and to elucidate the complex pathogenesis of the disease.

Inflammatory diseases trigger local cellular or environmental stress in certain tissue regions, leading to the activation of innate immune responses, the production of inflammatory mediators, and tissue damage [31].

PPARA has an important role in reducing inflammation. PPARA activity has an effect on neutrophils and macrophages in both acute and chronic inflammatory diseases. Leukotriene B4 (LTB4), a potent chemotactic

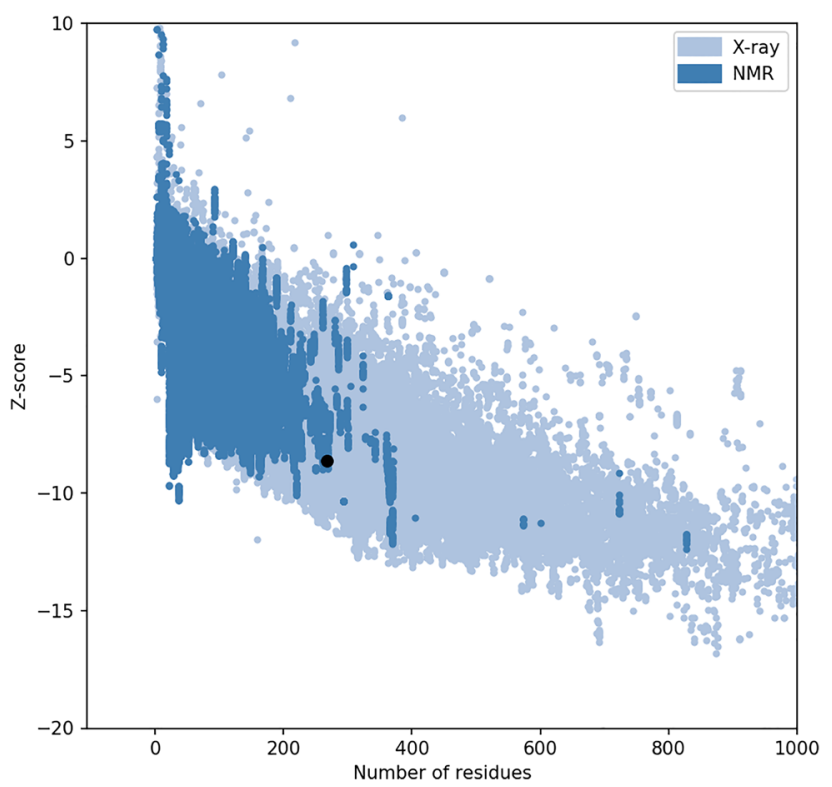

Figure 2: Quality (Z) score of homology model of polymorphic PPARA. inflammatory eicosanoid, is an endogenous PPARA ligand. Like other PPARA ligands, it induces the transcription of the genes of $\beta$ - and $\omega$-oxidation pathways that neutralize and reduce LTB4, to regulate inflammatory response. PPARA regulates the duration of the inflammatory response by limiting cytokine expression and inducing genes that metabolize LTB4 [32, 33].

New bone formation in axSpA plays an important role in the pathogenesis of the disease. Osteoblasting activity and ankylosis emerge as an important phenomenon that reduces patient comfort and quality of life by causing deformation in

Table 3: PPARA docking scores.

\section{Wild type PPARA-ligand}

\begin{tabular}{|c|c|c|c|c|c|}
\hline Binding Energy & LigandEff & ICons & Vdw-hb DE & Elect. & İnternal \\
\hline-11.58 & -0.3 & $3.23 \mathrm{nM}$ & -15.02 & 0.16 & -1.58 \\
\hline-11.49 & -0.3 & $3.70 \mathrm{nM}$ & -14.91 & 0.14 & -1.1 \\
\hline-11.27 & -0.3 & $5.46 \mathrm{nM}$ & -14.73 & 0.18 & -1.84 \\
\hline-11.23 & -0.3 & $5.83 \mathrm{nM}$ & -14.6 & 0.09 & -1.39 \\
\hline-11.13 & -0.29 & $6.9 \mathrm{nM}$ & -14.52 & 0.1 & -1.64 \\
\hline-11.12 & -0.29 & $7.06 \mathrm{nM}$ & -14.53 & 0.13 & -1.31 \\
\hline-11.09 & -0.29 & $7.39 \mathrm{nM}$ & -14.39 & 0.01 & -2.14 \\
\hline-11.08 & -0.29 & $7.53 \mathrm{nM}$ & -14.47 & 0.1 & -1.56 \\
\hline-11.06 & -0.29 & $7.8 \mathrm{nM}$ & -14.4 & 0.06 & -1.76 \\
\hline-11.03 & -0.29 & $8.26 \mathrm{nM}$ & -14.4 & 0.09 & -1.96 \\
\hline
\end{tabular}

Polymorphic PPARA-ligand

\begin{tabular}{lrrrrr}
\hline-10.92 & -0.29 & $9.89 \mathrm{nM}$ & -12.93 & -1.27 & -1.39 \\
-10.79 & -0.28 & $12.42 \mathrm{nM}$ & -13.23 & -0.84 & -1.51 \\
-10.78 & -0.28 & $12.54 \mathrm{nM}$ & -12.74 & -1.32 & -1.19 \\
-10.66 & -0.28 & $15.32 \mathrm{nM}$ & -13.18 & -0.76 & -1.39 \\
-10.38 & -0.27 & 24.63 & -13.5 & -0.16 & -1.13 \\
-10.32 & -0.27 & 27.3 & -12.46 & -1.14 & -2.37 \\
-10.3 & -0.27 & 28.39 & -13.18 & -0.39 & -1.8 \\
-10.27 & -0.27 & 29.62 & -12.44 & -1.11 & -1.8 \\
-10.22 & -0.27 & 32.23 & -12.41 & -1.09 & -2.11 \\
-10.1 & -0.27 & 39.59 & -13.03 & -0.35 & -1.62 \\
\hline
\end{tabular}

LigandEff, Ligand efficiency; ICons, inbibition concentration; Vdw-hb $\mathrm{DE}$, vander-walls - hydrogen bonds desolve energy; Elect, elektrostatic energy; İnternal, internal energy. 
A

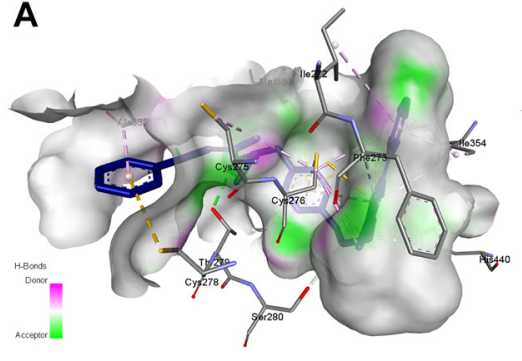

B

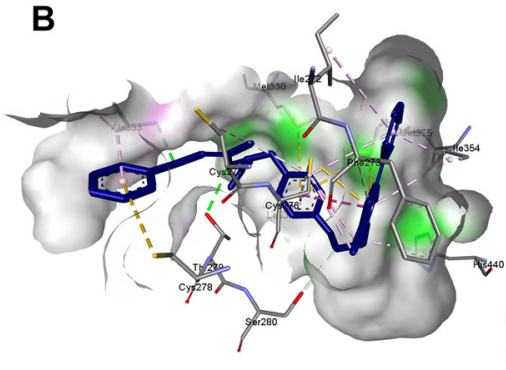

C

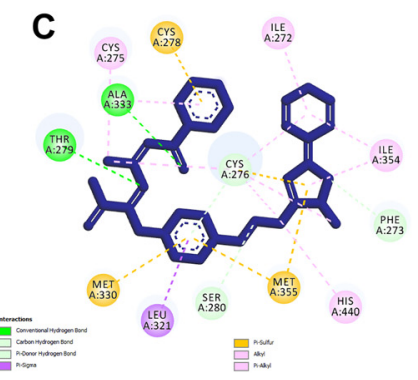

Figure 3: Illustration of wild type PPARA interaction with ligand at lowest binding energy. (A) Surface illustration of ligand receptor interaction, (B) reverse slide illustration, (C) diagram illustration of ligand receptor interaction.
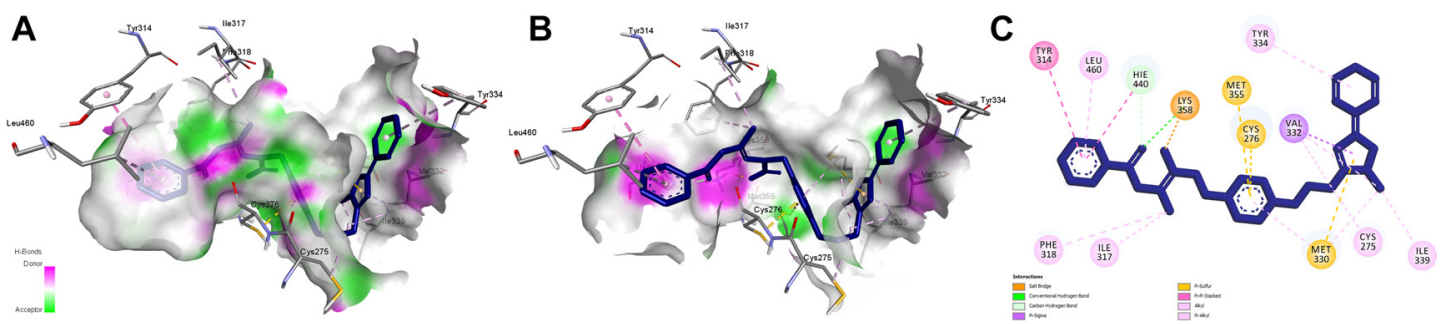

Figure 4: Illustration of polymorphic PPARA interaction with ligand at lowest binding energy. (A) Surface illustration of ligand receptor interaction, (B) reverse slide illustration, (C) diagram illustration of ligand receptor interaction.

vertebral bones. Excessive bone and ankylosis formation in axSpA is thought to be caused by the immune response and accompanying inflammation [34].

Previous studies conducted by our study group showed that the polymorphic changes in $5^{\prime}$ untranslated region of showed that PPARA is associated with disease risk PPARA $(\mathrm{p}<0.001, \mathrm{OR}=2.262,95 \% \mathrm{CI}=1.462-3.499$ for rs1800204; $\mathrm{p}=0.040, \mathrm{OR}=1.561,95 \% \mathrm{CI}=1.020-2.391$ for rs4253657; $\mathrm{p}=0.005, \mathrm{OR}=1.851,95 \% \mathrm{CI}=1.200-2.855$ for rs139090922) and this association may result in alteration in the expression level of the gene [35].

It is thought that PPARA, which we evaluated in our study, also inhibits osteoclasts and causes an increase in bone mineral density, and may play a role in cortical bone development, which plays a role in the pathogenesis of the disease [36].

TNF (Tumor Necrozis Factor) down-regulates bone formation and induces bone resorption by inducing proteins such as Dkk-1 and Sclerostin. Although it is a downstream regulator of bone formation, TNF does not have a key trigger role in the cortical bone formation process. For this reason, the roles of cytokines and mediators, whose activities change with the disease, in the formation of new bone should be examined. In our study, it was observed that the expression of PPARA positively associated with osteoblasting activity decreased. Despite the indirect effect of TNF on osteoclasting activity, the decrease in the expression of PPARA, which is thought to have a positive role in ossification and ankylosis, which is thought to occur due to inflammation and inflammatory response, and is found to be associated with disease development [35], was found to be compatible with the disease activity index scores (BASDAI).

It is known that amino acid changes seen in the protein primary sequence will cause changes in the 3-dimensional structure and functional properties of the protein [37, 38].

PPARA is a ligand-activated transcription factor. Activation of PPARA by agonist ligands triggers conformational changes, including stabilization of C-terminal helix-12 and enhancement of heterodimerization of PPARA with the retinoid-X receptor [39]. These conformational changes result in the activation of nuclear receptor coactivators and ultimately gene transcription [40].

PPARA consists of four functional sites: modulator region, DNA binding domain, hinge and ligand binding domain [41]. The PPARA ligand binding domain contains 2 different binding sites that interact with each other [42]. In this study, the ligand binding domain between $\mathrm{H}^{\prime}$ and $\mathrm{H} 3$, called the omega loop, was examined. This region promotes local stabilization of the ligand binding site and activation function-2 (AF-2) in the ligand-PPARA interaction. In addition to ligand recognition and binding, the ligand binding site has additional functions such as regulating interactions with cofactors involved in signal transduction during transcription and binding to homodimerization or heterodimerization partners [43]. It is thought that positional changes due to polymorphic changes in the PPARA omega loop region may affect 


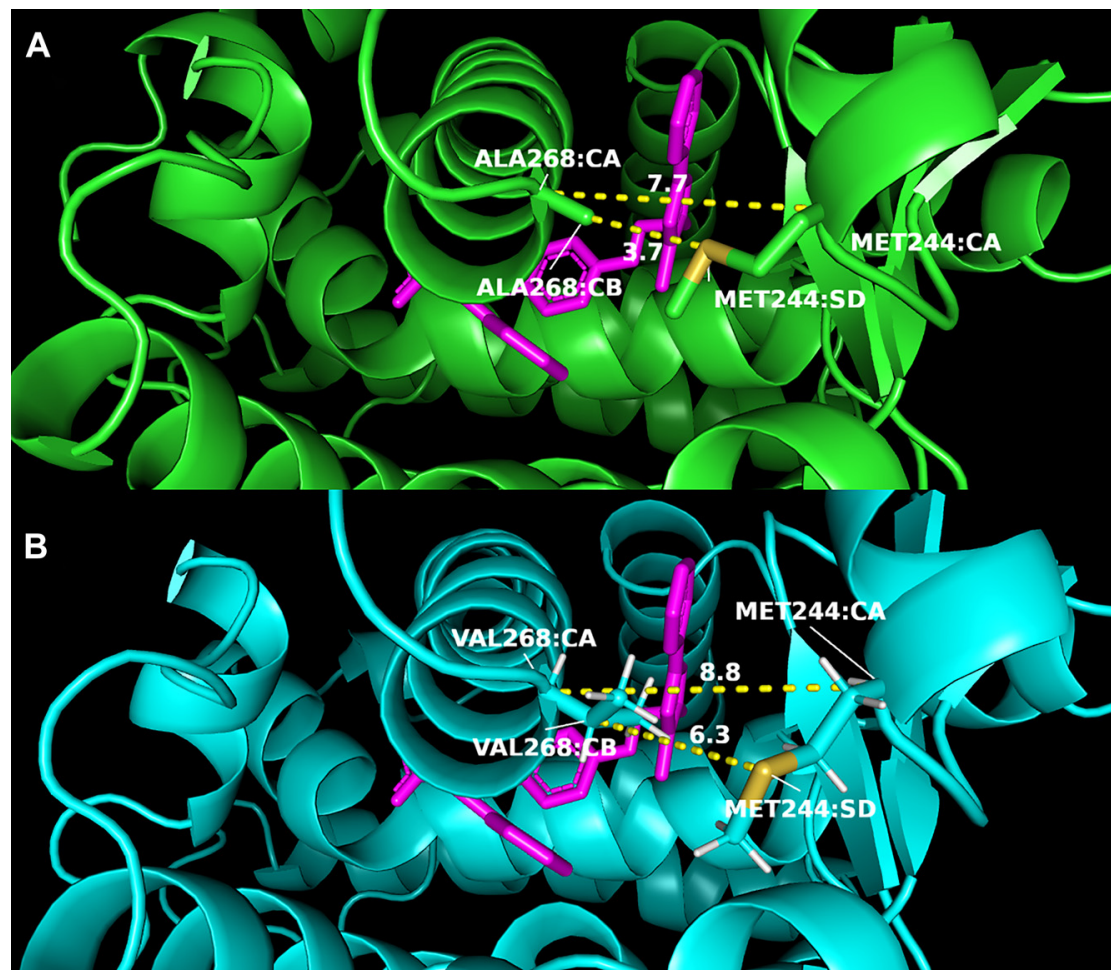

Figure 5: Cartoon representation of positional changes in the $\mathrm{A} 268 \mathrm{~V}$ polymorphic region. (A) Wild type PPARA, (B) polymorphic PPARA. functional properties of PPARA. We found that the NG_012204.2:p.Ala268Val polymorphism caused $1.1 \AA$ positional opening in the ligand entry pocket of PPARA (Figure 5), which resulted in a decrease in ligand affinity (Table 3) and a decrease in expression of PPARA. Sapone et al. showed that the NG_012204.2:p.Leu162Val mutation in DNA binding domain of PPARA consisting of two zinc finger motifs increased PPARA expression up to 5-fold in the presence of a potent PPARA activator [44].

\section{Conclusion}

This is the second study in which PPARA polymorphism is associated with axSPA disease risk. In the first study carried out by our study group, it was shown that some polymorphic changes in 5'UTR were associated with disease risk [35]. PPARA polymorphisms have been shown to be associated with cancer, cardiovascular diseases and metabolic disorder risk [45]. This study showed that PPARA polymorphism could be an important marker for the diagnosis of axSpA. This study, in which changes in genetic and protein structure are revealed, provides important data for elucidating the molecular mechanism of the disease. In order to elucidate the pathogenesis of the disease, it is necessary to enlighten the changes that occur in the relationship of PPARA with the genes it interacts after polymorphic change.
Research funding: This study was supported by Munzur University Health Faculty Research Budget and Munzur University Scientific Research Department (Grant number: MFMUB017-09).

Author contributions: All authors have accepted responsibility for the entire content of this manuscript and approved its submission.

Competing interests: Authors state no conflict of interest. Informed consent: Informed consent was obtained from all individuals included in this study.

Ethical approval: Ethical rules were followed in this study and written consent of volunteers was obtained. The study protocol was approved by the ethics committee of Malatya Clinical Investigations (2016/44). The study followed the ethical standards of the Helsinki Declaration.

\section{References}

1. Sharma SM, Choi D, Planck SR, Harrington CA, Austin CR, Lewis JA, et al. Insights in to the pathogenesis of axial spondyloarthropathy based on gene expression profiles. Arthritis Res Ther 2009;11: R168.

2. Zhao J, Huang C, Huang H, Pan J-K, Zeng L-F, Luo M-H, et al. Prevalence of ankylosing spondylitis in a Chinese population: a systematic review and meta-analysis. Rheumatol Int 2020;40: 859-72.

3. Dean LE, Jones GT, Macdonald AG, Downham C, Sturrock RD, Macfarlane GJ. Global prevalence of ankylosing spondylitis. Rheumatol 2014;53:650-7. 
4. Sieper J, Poddubnyy D. Axial spondyloarthritis. The Lancet; 2017. [Online] 2017.

5. Poddubnyy D, Sieper J. Mechanism of new bone formation in axial spondyloarthritis. Curr Rheumatol Rep 2017;19:1-9.

6. Ramiro S, Van Tubergen A, Stolwijk C, van der Heijde D, Royston $P$, Landewé R. Reference intervals of spinal mobility measures in normal individuals: the mobility study. Ann Rheum Dis 2015;74: 1218-24.

7. Castro-Zunti R, Park EH, Choi Y, Jin GY, Ko S-b. Early detection of ankylosing spondylitis using texture features and statistical machine learning, and deep learning, with some patient age analysis. Comput Med Imaging Graph 2020;82:101718.

8. Yi E, Ahuja A, Rajput T, George AT, Park Y. Clinical, economic, and humanistic burden associated with delayed diagnosis of axial spondyloarthritis: a systematic review. Rheumatol Ther 2020;7: 65-87.

9. Wang R, Ward MM. Epidemiology of axial spondyloarthritis: an update. Curr Opin Rheumatol 2018;30:137-43.

10. Carvalho PD, Machado PM. How to investigate: early axial spondyloarthritis. Best Pract Res Clin Rheumatol 2019;33: 101427.

11. Bougarne N, Mylka V, Ratman D, Beck IM, Thommis J, De Cauwer L, et al. Mechanisms underlying the functional cooperation between PPARalpha and GRalpha to attenuate inflammatory responses. Front Immunol 2019;10:1-14.

12. Silva AKS, Peixoto CA. Role of peroxisome proliferator-activated receptors in non-alcoholic fatty liver disease inflammation. Cell Mol Life Sci 2018;75:2951-61.

13. Ahmed W, Ziouzenkova O, Brown J, Devchand P, Francis S, Kadakia M, et al. PPARs and their metabolic modulation: new mechanisms for transcriptional regulation? J Intern Med 2007; 262:184-98.

14. Ramanan S, Zhao W, Riddle DR, Robbins ME. Review article: role of PPARs in radiation-induced brain injury. PPAR Res 2010;2010: 1-12.

15. Hill MR, Clarke S, Rodgers K, Thornhill B, Peters JM, Gonzalez FJ, et al. Effect of peroxisome proliferator-activated receptor alpha activators on tumor necrosis factor expression in mice during endotoxemia. Infect Immun Am Soc Microbiol 1999;67:3488-93.

16. O’Rielly DD, Zhai G, Rahman P. Expression and metabolomic profiling in axial spondyloarthritis. Curr Rheumatol Rep 2018; 20:51.

17. Costantino F, Breban M, Garchon HJ. Genetics and functional genomics of spondyloarthritis. Front Immunol 2018;9:2933.

18. Waterhouse A, Bertoni M, Bienert S, Studer G, Tauriello G, Gumienny R, et al. Swiss-Model: homology modelling of protein structures and complexes. Nucleic Acids Res 2018;46: W296-303.

19. Kumar S, Stecher G, Li M, Knyaz C, Tamura K. MEGA X: molecular evolutionary genetics analysis across computing platforms. Mol Biol Evol 2018;35:1547-9.

20. Wiederstein M, Sippl MJ. ProSA-web: interactive web service for the recognition of errors in three-dimensional structures of proteins. Nucleic Acids Res 2007;35:407-10.

21. Chen VB, Arendall WB, Headd JJ, Keedy DA, Immormino RM, Kapral G, et al. MolProbity: all-atom structure validation for macromolecular crystallography. Acta Crystallogr Sect D Biol Crystallogr 2010;66:12-21.
22. Zhang Y, Skolnick J. Scoring function for automated assessment of protein structure template quality. Proteins Struct Funct Genet 2004;57:702-10.

23. Pires DEV, Ascher DB, Blundell TL. MCSM: predicting the effects of mutations in proteins using graph-based signatures.

Bioinformatics 2014;30:335-42.

24. Pires DEV, Ascher DB, Blundell TL. DUET: a server for predicting effects of mutations on protein stability using an integrated computational approach. Nucleic Acids Res 2014;42: W314-9.

25. Rodrigues CHM, Pires DEV, Ascher DB. DynaMut2: assessing changes in stability and flexibility upon single and multiple point missense mutations. Protein Sci 2021;30:60-9.

26. Pandurangan AP, Ochoa-Montaño B, Ascher DB, Blundell TL. SDM: a server for predicting effects of mutations on protein stability. Nucleic Acids Res 2017;45:W229-35.

27. Steffen C, Thomas K, Huniar U, Hellweg A, Rubner O, Schroer A. AutoDock4 and AutoDockTools4: automated docking with selective receptor flexibility. J Comput Chem 2010;31: 2967-70.

28. Morris GM, Goodsell DS, Halliday RS, Huey R, Hart WE, Belew RK, et al. Automated docking using a Lamarckian genetic algorithm and an empirical binding free energy function. J Comput Chem 1998;19:1639-62.

29. Furst DE, Louie JS. Targeting inflammatory pathways in axial spondyloarthritis. Arthritis Res Ther 2019;21:1-15.

30. Zhao SS, Robertson S, Reich T, Harrison NL, Moots RJ, Goodson NJ. Prevalence and impact of comorbidities in axial spondyloarthritis: systematic review and meta-analysis. Revmatol 2020;59: IV47-57.

31. Park H, Bourla AB, Kastner DL, Colbert RA, Siegel RM. Lighting the fires within: the cell biology of autoinflammatory diseases. Nat Rev Immunol 2012;12:570-80.

32. Desvergne B, Wahli W. Peroxisome proliferator-activated receptors: nuclear control of metabolism. Endocr Rev 1999;20: 649-88.

33. Devchand PR, Keller H, Peters JM, Vazquez M, Gonzalez FJ, Wahli W. The PPAR $\alpha$-leukotriene B4 pathway to inflammation control. Nature 1996;384:39-43.

34. Schett $G$, Rudwaleit M. Can we stop progression of ankylosing spondylitis? Best Pract Res Clin Rheumatol 2010;24:363-71.

35. Akbulut E, Özgen M. Contribution of polymorphism in the noncoding region of PPAR $\alpha$ to the development of axial spondyloarthritis. Adıyaman Univ J Sci 2020;10:55-64.

36. Ralston SH, Urquhart GDK, Brzeski M, Sturrock RD. Prevalence of vertebral compression fractures due to osteoporosis in ankylosing spondylitis. Br Med J 1990;300:563-5.

37. Akbulut E. Mutations in the SARS CoV-2 spike protein may cause functional changes in the protein quaternary structure. Turkish J Biochem 2021;46:137-44.

38. Kamburov A, Lawrence MS, Polak P, Leshchiner I, Lage K, Golub TR, et al. Comprehensive assessment of cancer missense mutation clustering in protein structures. Proc Natl Acad Sci 2015;112: E5486-95.

39. Kota BP, Huang THW, Roufogalis BD. An overview on biological mechanisms of PPARs. Pharmacol Res 2005;51:85-94.

40. Kersten S, Desvergne B, Wahli W. Roles of PPARS in health and disease. Nature 2000;405:421-4. 
41. Giguere V. Orphan nuclear receptors: from gene to function. Endocr Rev 1999;20:689-725.

42. Bernardes A, Souza PCT, Muniz JRC, Ricci CG, Ayers SD, Parekh NM, et al. Molecular mechanism of peroxisome proliferator-activated receptor $\alpha$ activation by WY14643: a new mode of ligand recognition and receptor stabilization. J Mol Biol 2013;425:2878-93.

43. Bulynko YA, O’Malley BW. Nuclear receptor coactivators: structural and functional biochemistry. Biochemistry 2011;50: 313-28.
44. Sapone A, Peters JM, Sakai S, Tomita S, Papiha SS, Dai R, et al. The human peroxisome proliferator-activated receptor $\alpha$ gene: identification and functional characterization of two natural allelic variants. Pharmacogenetics 2000;10: 321-33.

45. Dhaini HR, Daher Z. Genetic polymorphisms of PPAR genes and human cancers: evidence for gene-environment interactions. J Environ Sci Heal - Part C Environ Carcinog Ecotoxicol Rev 2019;37: 146-79. 